\title{
Treatment of Tannery Wastewater by Electrocoagulation using Aluminium and Iron Electrodes
}

\author{
Kiran Kumar H S, Lokeshappa B, Mohammad Rizwan M R
}

\begin{abstract}
This Tannery industry is one of oldest industry the effluent is highly complex and characterized by high Biochemical Oxygen Demand (BOD), Chemical Oxygen Demand (COD), suspended solids, dissolved solids, total solids, and color. Untreated Tannery wastewater when discharged directly into the water bodies or into open lands cause irreversible damage to environment. Electrocoagulation is one of the most important electrochemical treatment employed for industrial wastewater treatment to treat highly polluted industrial effluents which have high suspended and colloidal materials, BOD, COD in wastewater.
\end{abstract}

Electrocoagulation treatment is used in this study to study the removal efficiency of BOD, COD, Chromium (Cr) Total Dissolved Solids (TDS) and the effect of $p H$ of tannery wastewater. The experiments were conducted using aluminum and iron as plane and punched electrodes. When aluminum Plane and punched electrodes were used the optimum removal efficiency for plain electrodes was found to be BOD-89.66\%, COD-96.21\%, Cr-96.05\% and TDS-95.77\% for punched electrodes BOD-90.86\%, COD-98.62\%, Cr-96.94\% and TDS96.92\% and for iron plane electrodes BOD-87.57\%, COD94.77\%, Cr-93.42\% and TDS-93.08\% for iron punched electrodes BOD-89.01\%, 96.59\%, Cr-94.66\% and TDS-95.0\% at pH of 9, Voltage $20 \mathrm{~V}$, for electrode distance of $1 \mathrm{~cm}$ and 90 minutes electrolysis duration. The Electrocoagulation treatment has proved to be economical and efficient method for the treatment of tannery wastewater rather than chemical coagulation.

Keywords- Tannery wastewater; Electrocoagulation; Aluminum electrodes; iron electrodes; plane and punched electrodes; BOD; COD; TDS and Chromium.

\section{INTRODUCTION}

Tanning is claimed as the second oldest profession in the world. A total of 1800 million square feet of leather was produced per year from all the industries. India is the third largest producer of leather in the world, behind China and Italy [1]. In India the most of the tannery industries adopted inefficient and conventional production methods to produce leather. The waste water generated from these industries characterized by high BOD, COD, suspended solids, dissolved solids, color and strong odor. Inorganic chemicals such as chlorides and Chromium. [2]. This results for the generation of large amount of low biodegradable wastewater. Inefficient treatment of wastewater causes decreased use of raw materials and also cost for economy [3].

Revised Manuscript Received on November 25, 2019.

Kiran Kumar H S, Assistant professor, Civil engineering, GM Institute of Technology, Davanagere, Karnataka, India

Lokeshappa B, Associate professor, Civil engineering, UBDT College of Engineering, Davanagere, Karnataka, India

Mohammad Rizwan M R, M Tech student, Environmental engineering, UBDT College of Engineering, Davanagere, Karnataka, India
Untreated wastewater if discharged to the stream, high inorganic solids cause hardness and high alkalinity in the waste leads to the formation of slimy layers on the streams High BOD depletes the DO contents in the streams causes lack of oxygen to the aquatic life. High suspended solids increase the load to the treatment plants. Degradable matter leads to the propagation of pathogens. High chromium as carcinogenic to the human health. Untreated wastewater if discharge to the streams not only affects fish but also affects the health of the cattle and vegetative system along the shore line. It also leads to the pollution of soil, it affects the soil fertility alters soil $\mathrm{pH}$, due to high organic contents it causes clogs to the soil and impair soil structure leads to soil degradation. [4].

Electro-chemical treatment of tannery wastewater has recently attracted great attention to researchers for its simplicity and ease of operation. When conventional physico chemical process fails to treat the polluted effluent efficiently, electrochemical methods such as electrocoagulation plays a prominent role in not only decreasing the pollutional load but also proves to be efficient in removal of pollutants, besides it is also proving that the byproducts obtained can be utilizable. The sludge can be utilized as a manure.

\subsection{Impacts of Tannery Wastewater on Environment}

Improper management and inadequate treatment technology create heavy pollutional load to the environment. $95 \%$ of the tannery industries are still adopted traditional treatment methods. Due to its unpleasant odor it creates unnecessary nuisance [5].

High inorganic solids cause hardness to the streams if untreated, high alkalinity in the waste leads to slimy layer formed to the streams. High BOD depletes the Dissolved Oxygen (DO) contents in the streams causes lack of oxygen to the aquatic life. High suspended solids increase the load to the treatment plants. Degradable matter leads to the propagation of pathogens. High chromium act as carcinogenic to the human health [6]. Untreated wastewater if discharge to the streams not only affects fish but also affects the health of the cattle and vegetative system along the shore line. It also leads to the pollution of soil, it affects the soil fertility alters soil $\mathrm{pH}$, due to high organic contents it causes clogs to the soil and impair soil structure leads to Soil degradation [7].

People who are working in the industry environment cause severe skin irritation, respiratory disorders. Long term exposure to the waste leads to depression, headache, dizziness eye and skin irritation. The chromium act as a carcinogenic and causes cancer [8].

Blue Eyes Intelligence Engineering \& Sciences Publication 


\subsection{Treatment of Tannery Wastewater}

The different treatment methods adopted for tannery wastewater are shown in the Table 1

Table 1. Treatment Methods Available for Treatment of Tannery Waste Water

\begin{tabular}{|l|l|}
\hline Pre-treatment & Mechanical screening, equalization \\
\hline Primary treatment & $\begin{array}{l}\text { Sulfide removal, Chromium removal from } \\
\text { tanning effluents Physical-chemical } \\
\text { treatment for BOD removal and } \\
\text { neutralization }\end{array}$ \\
\hline Secondary treatment & $\begin{array}{l}\text { Biological treatment such as Activated } \\
\text { sludge process, Lagooning }\end{array}$ \\
\hline Tertiary treatment & $\begin{array}{l}\text { Nitrification and denitrification, } \\
\text { Electrochemical methods }\end{array}$ \\
\hline
\end{tabular}

\subsection{Theory of Electrocoagulation}

The process of applying electric current in to an aqueous medium in an electrochemical cell using electrode is called electrocoagulation. The principle of electrocoagulation process depends on, responses of water contaminants to a strong electric fields and electrically induced oxidation and reduction reactions. Electrocoagulation utilizes direct current to remove undesirable contaminants by chemical reactions and precipitation. The different types of electrodes used in this process are Aluminum, Zinc, Copper, Iron [9].

The process of coagulation of pollutants in the solution through various stages is listed below

1. Electrolytic oxidation takes place at the anode (Sacrificial electrode) results in the formation of coagulants.

2. Weakening of the pollutants, particulate suspension and breaking of emulsions.

3. Adsorption of soluble or colloidal pollutants on coagulants, and removal by sedimentation or floatation.

When a potential is applied from an external power source, the anode material undergoes oxidation, while cathode undergo reduction.

The electrochemical reactions with metal $M$ as anode is summarized as follows [10].

\section{Reactions at anode:}

$$
\begin{aligned}
& M_{(s)} \rightarrow M_{(a q)}^{n+}+n e^{-} \\
& 2 \mathrm{H}_{2} \mathrm{O}_{(\mathrm{l})}+2 e^{-} \rightarrow 4 \mathrm{H}_{(a q)}^{+}+\mathrm{O}_{2(g)}+4 e^{-} \\
& \text {Reactions at cathode: }
\end{aligned}
$$

$$
\begin{aligned}
& M_{(a q)}^{n+}+n e^{-} \rightarrow M_{(s)} \\
& 2 \mathrm{H}_{2} \mathrm{O}_{(\mathrm{l})}+2 e^{-} \rightarrow \mathrm{H}_{2(g)}+2 \mathrm{OH}^{-}
\end{aligned}
$$

When aluminum or iron electrodes were used the generated, $\mathrm{Fe}(\mathrm{aq})^{3+}$ or $\mathrm{Al}(\mathrm{aq})^{3+}$ ions will instantaneously undergo spontaneous reactions to produces the corresponding hydroxides and polyhydroxides. This hydroxide and poly hydroxide settle in the form of precipitate [11].

Following reactions are carried out for aluminum electrodes:

Anode

$A l^{-3} e \rightarrow A l^{3+}$

\section{Alkaline condition}

$\mathrm{Al}^{3+}+3 \mathrm{OH}^{-} \rightarrow \mathrm{Al}(\mathrm{OH})_{3}$

\section{Acidic condition \\ $\mathrm{Al}^{3+}+3 \mathrm{H}_{2} \mathrm{O} \rightarrow \mathrm{Al}(\mathrm{OH})_{3}+3 \mathrm{H}^{+}$ \\ $2 \mathrm{H}_{2} \mathrm{O}-4 e \rightarrow \mathrm{O}_{2}+4 \mathrm{H}^{+}$}

\section{Cathode}

$2 \mathrm{H}_{2} \mathrm{O}+2 \mathrm{e} \rightarrow \mathrm{H}_{2}+\mathrm{OH}^{-}$

Waste water containing $\mathrm{Cr}^{6+}\left(\mathrm{CrO}_{4}\right)$ ions can be removed by the electrocoagulation using iron as the sacrificial anode. The ferrous ion $\left(\mathrm{Fe}^{2+}\right)$ generated by electro-oxidation of the iron (anode) can reduce $\mathrm{Cr}^{6+}$ to $\mathrm{Cr}^{3+}$ under alkaline conditions and is itself oxidized to ferric $\left(\mathrm{Fe}^{3+}\right)$ ion according to the below equations

$\mathrm{CrO}_{4}^{2-}+3 \mathrm{Fe}^{2+}+4 \mathrm{H}_{2} \mathrm{O} \rightarrow 3 \mathrm{Fe}^{3+}+\mathrm{Cr}^{3+}+8 \mathrm{OH}^{-}$

$\mathrm{CrO}_{4}^{2-}+3 \mathrm{Fe}^{2+}+4 \mathrm{H}_{2} \mathrm{O}+4 \mathrm{OH}^{-} \rightarrow 3 \mathrm{Fe}(\mathrm{OH})_{3}+\mathrm{Cr}(\mathrm{OH})_{3}$

The $\mathrm{Cr}^{3+}(\mathrm{aq})$ ions are then precipitated as $\mathrm{Cr}(\mathrm{OH})_{3}(\mathrm{~s})$ by raising the $\mathrm{pH}$ of the solution.

The mechanism of electrocoagulation was schematically shown in the Figure 1

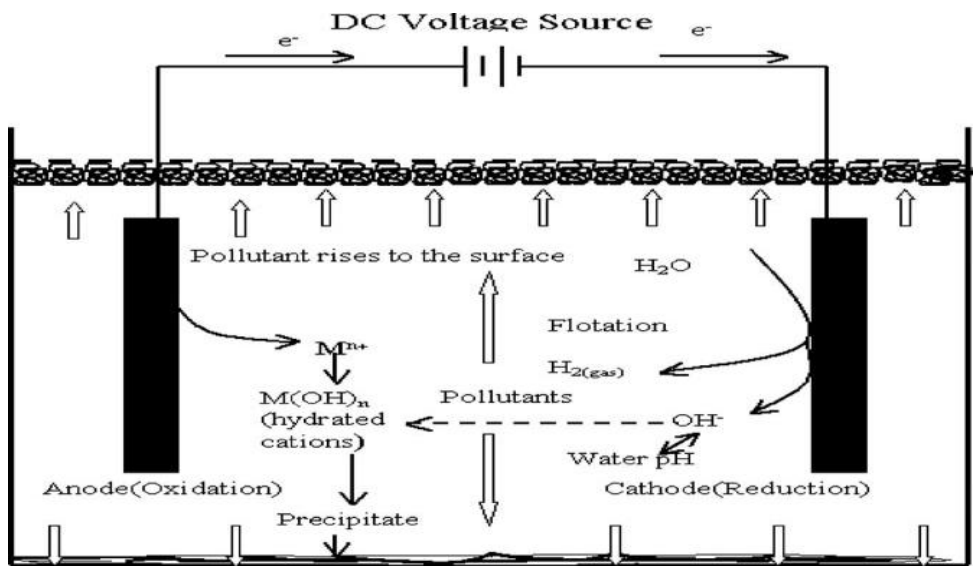

Figure 1. Schematic Diagram of a Bench-Scale Two-electrodes Electrocoagulation Cell 


\section{MATERIALS AND METHODS}

\subsection{Materials}

The sample to be studied was collected from a common effluent treatment plant at the Vanitec tannery wastewater treatment plant, Tamil Nadu. The sample was collected according to the standards. The sample was preserved at $6^{\circ} \mathrm{C}$ and brings it to the laboratory at standard condition before analysis. The aluminium and iron plane and punched electrodes of dimension $15 \mathrm{~cm} \times 5 \mathrm{~cm} \times 0.2 \mathrm{~cm}$ were used for the experimentation and a glass container as an electrochemical cell with a working capacity of 2 liters. The composition of the tannery wastewater is determined using Standard Methods and are presented in Table 2.

Table 2. Initial Characteristics of Raw Tannery Wastewater

\begin{tabular}{|c|c|c|c|}
\hline S1 No & Parameter & Unit & Values \\
\hline 1 & Color & & Brown \\
\hline 2 & Temperature & ${ }^{\circ} \mathrm{C}$ & $24^{0}$ \\
\hline 3 & $\mathrm{pH}$ & - & 8.4 \\
\hline 4 & Turbidity & NTU & 727 \\
\hline
\end{tabular}

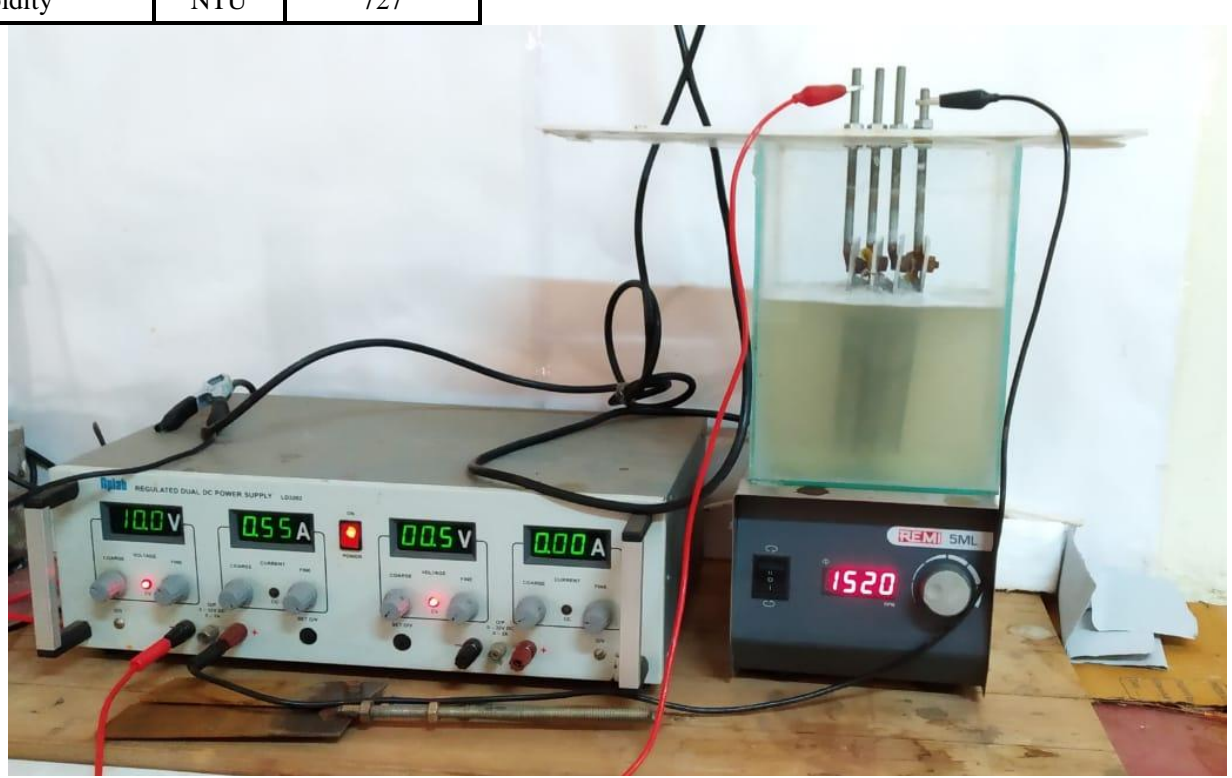

Figure 2. Laboratory Experimental Setup

\subsection{Experimental procedure}

The raw wastewater was diluted to $10 \%$ dilution before analysis. The monopolar electrodes were arranged in series and connected to a $0-30 \mathrm{~V}$ and $0-2 \mathrm{~A}$ DC power supply. Four numbers of electrodes were arranged in series, the end electrodes were connected to positive and negative terminals and the inner electrodes remains unconnected and acts as sacrificial electrodes. A constant gap of $1 \mathrm{~cm}, 1.5 \mathrm{~cm}$ and $2 \mathrm{~cm}$ was kept between the electrodes. The glass container was filled with 2 liters diluted wastewater and the initial $\mathrm{pH}$ was adjusted to 7,8 and 9 to determine the optimum $\mathrm{pH}$. The voltage in the DC power supply was adjusted to $10 \mathrm{~V}$, $15 \mathrm{~V}$ and $20 \mathrm{~V}$ to evaluate the optimum voltage. The electrolysis was carried out for 90 minutes and the samples were taken at an interval of 30 minutes. The collected sample was filtered with the filter paper and simultaneously the $\mathrm{pH}$ and TDS were measured. The filtered sample was preserved in a $60 \mathrm{ml}$ polythene bottle with tight lid in a refrigerator at below $6{ }^{0} \mathrm{C}$ to test other parameters. The BOD is measured using DO calculations, COD and chromium test

\begin{tabular}{|c|c|c|c|}
5 & TDS & $\mathrm{ppm}$ & 26000 \\
\hline 6 & $\mathrm{EC}$ & $\mathrm{S} / \mathrm{m}$ & 38806 \\
\hline 7 & BOD $_{5}$ & $\mathrm{mg} / \mathrm{L}$ & 2156 \\
\hline 8 & $\mathrm{COD}$ & $\mathrm{mg} / \mathrm{L}$ & 6100 \\
\hline 9 & Chromium & $\mathrm{mg} / \mathrm{L}$ & 14.6 \\
\hline
\end{tabular}

\subsection{Experimental Setup}

For the batch electro coagulation studies, the reactor was designed and fabricated using glass material with the total working volume, of 2 liter and with the dimensions of $22 \mathrm{~cm} \times 11 \mathrm{~cm} \times 10 \mathrm{~cm}$. The electro coagulation unit consists of four monopolar electrodes connected in series. The I DC power supply of 0-30V and 0$2 \mathrm{~A}$ was used as the power supply to the system. Plane and punched aluminium and iron electrodes having dimensions of $15 \mathrm{~cm} \times 5 \mathrm{~cm} \times 0.2 \mathrm{~cm}$. The distance between the electrodes were kept $1 \mathrm{~cm}, 1.5 \mathrm{~cm}$ and $2 \mathrm{~cm}$ to study and evaluate optimum distance. One set of electrodes were punched with a $5 \mathrm{~mm}$ diameter holes and a total of 5 numbers of holes were made. The below Figure 2. shows the laboratory experimental set up of electro coagulation 
Treatment of Tannery Wastewater by Electrocoagulation using Aluminium and Iron Electrodes

iron electrodes was found to be maximum at $\mathrm{pH} 8$.

Lower removal efficiency at $\mathrm{pH} 9$ is due to the predominance of an ineffecient adsorbant (monomeric $\mathrm{Al}(\mathrm{OH})_{4}{ }^{-}$anion) under alkaline conditions. At higher $\mathrm{pH}$ values, deposits on the anode surface lead to an increasing ohmic drop (because of the inert, little conducting layer formed) and to an increase in the electrical consumption.

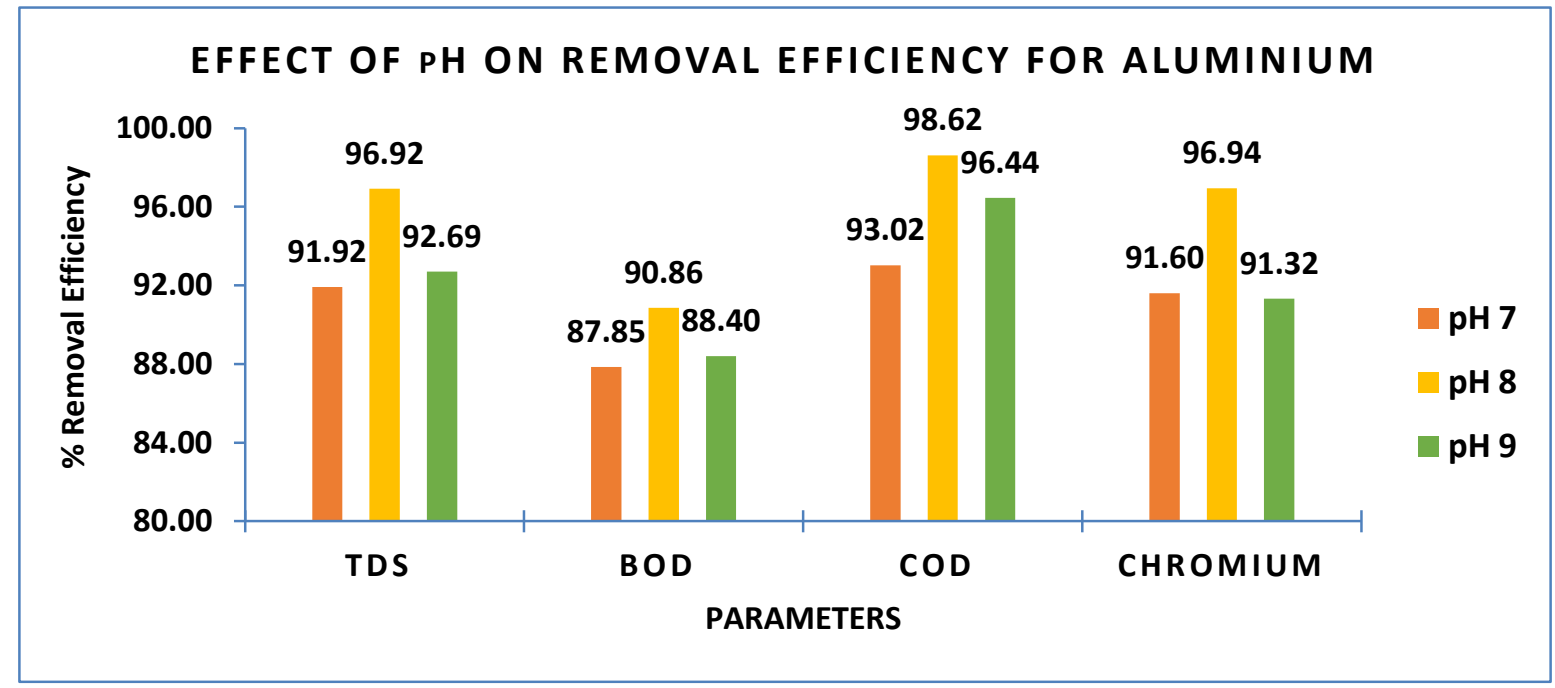

Figure 3.1 Effect of pH on Removal Efficiency for Aluminium Electrodes

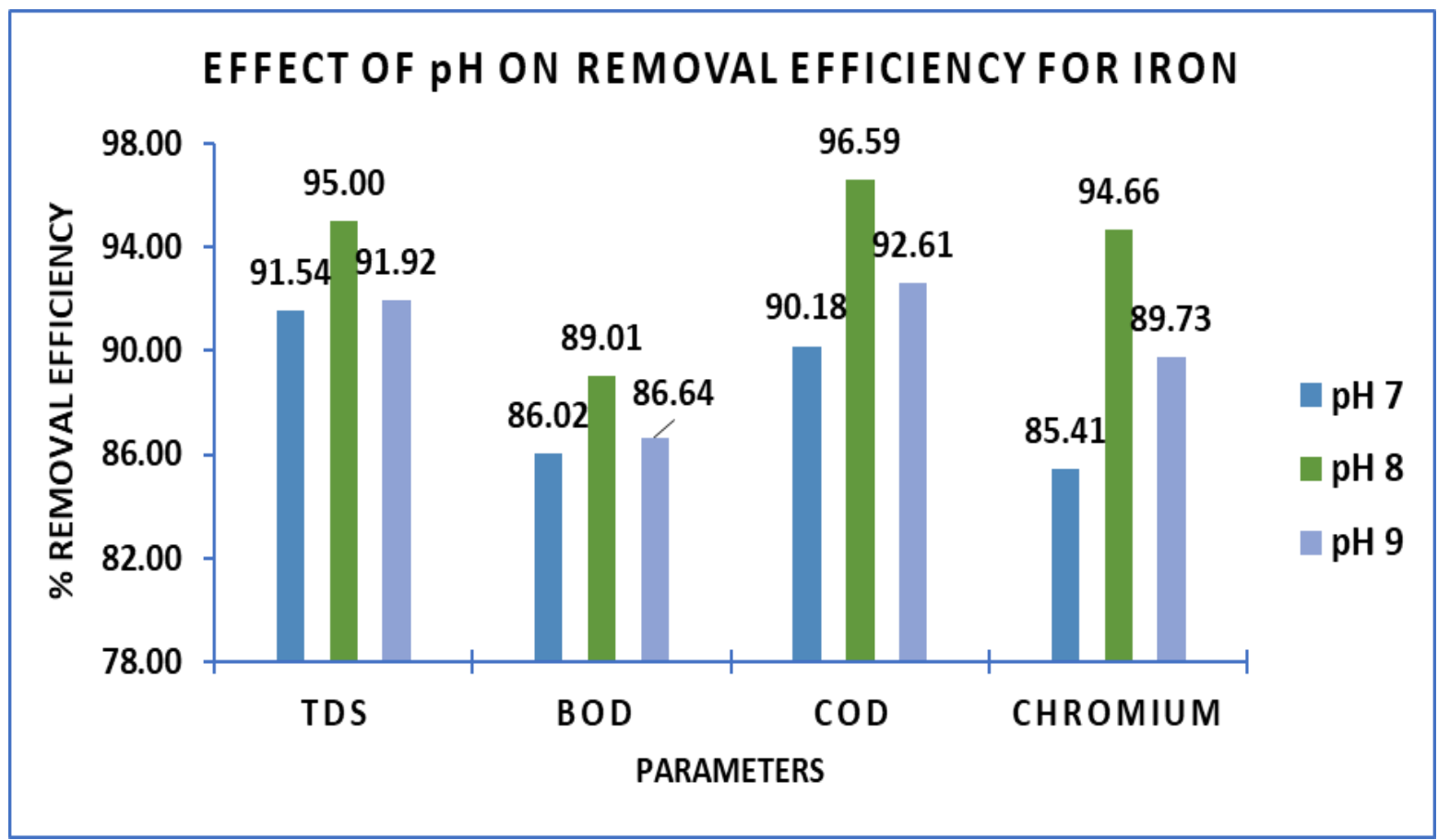

Figure 3.2 Effect of pH on Removal Efficiency for Iron Electrodes

\subsection{Effects of Voltage on Removal Efficiency}

The Figure 3.3 and 3.4 were plotted to study the effect of voltage on removal efficiencies of TDS, BOD, COD and Chromium. It was observed that at $10 \mathrm{~V}, 93.46 \%$ of COD removal efficiency was found. As the voltage increases the removal efficiency also increases. The graph shows removal efficiency of $98.62 \%$ for aluminum and $96.59 \%$ for iron was found to be at $20 \mathrm{~V}$ this is due to the fact that as the electrode potential increases the number of coagulant ions and, consequently, pollutant recovery rate increases. On the other hand, voltage density determines the speed and the amount of hydroxyl ion produced. The higher the hydroxyl ion production rate and, the greater the removal efficiency. 


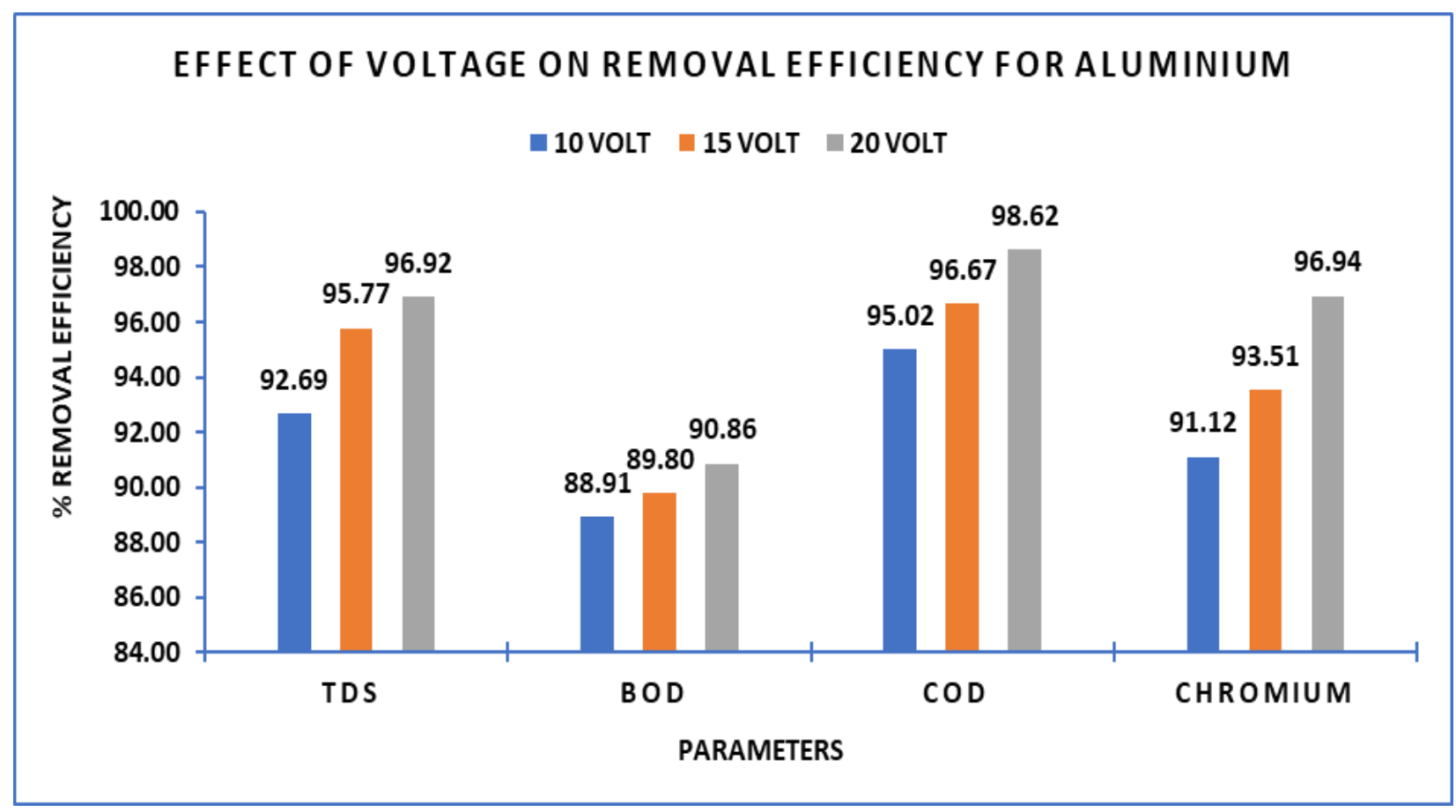

Figure 3.3 Effect of Voltage on Removal Efficiency for Aluminium Electrodes

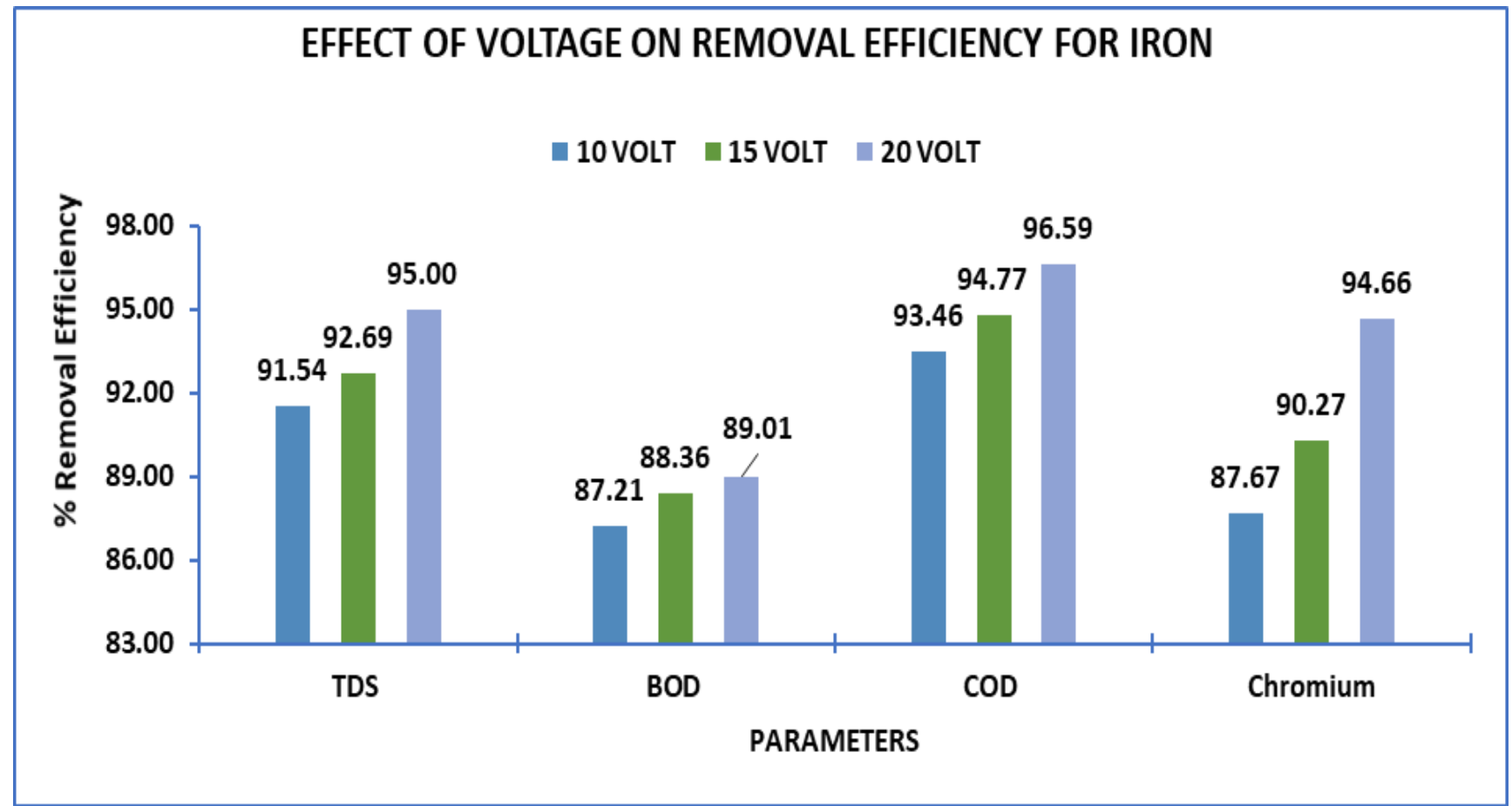

Figure 3.4 Effect of Voltage on Removal Efficiency for Iron Electrodes

3.3 Effects of Electrolysis Time on Removal Efficiency

The Figure 3.5 and 3.6 were plotted to study the effect of electrolysis time on removal efficiencies of TDS, BOD, COD and Chromium. It was observed that at 30 minutes of electrolysis time, $95.61 \%$ of COD removal efficiency was found. As the electrolysis time increases the removal efficiency also increases. The graph shows removal efficiency of $98.62 \%$ for aluminum and $96.59 \%$ for iron was found to be at 90 minutes of electrolysis time, As the electrolysis time increases the concentration of specific pollutants influences the stability of the passive layer of an electrode, this leads to the deposition of cations (pollutants) and sludge particles on the surface of electrode material and the formation of oxide layer which inhibits the dissolution of metal and thus causes a reduction in the yield of electrode with prolonged electrolysis time, thereby simultaneously removal efficiency also decreases as the electrolysis time increases. 


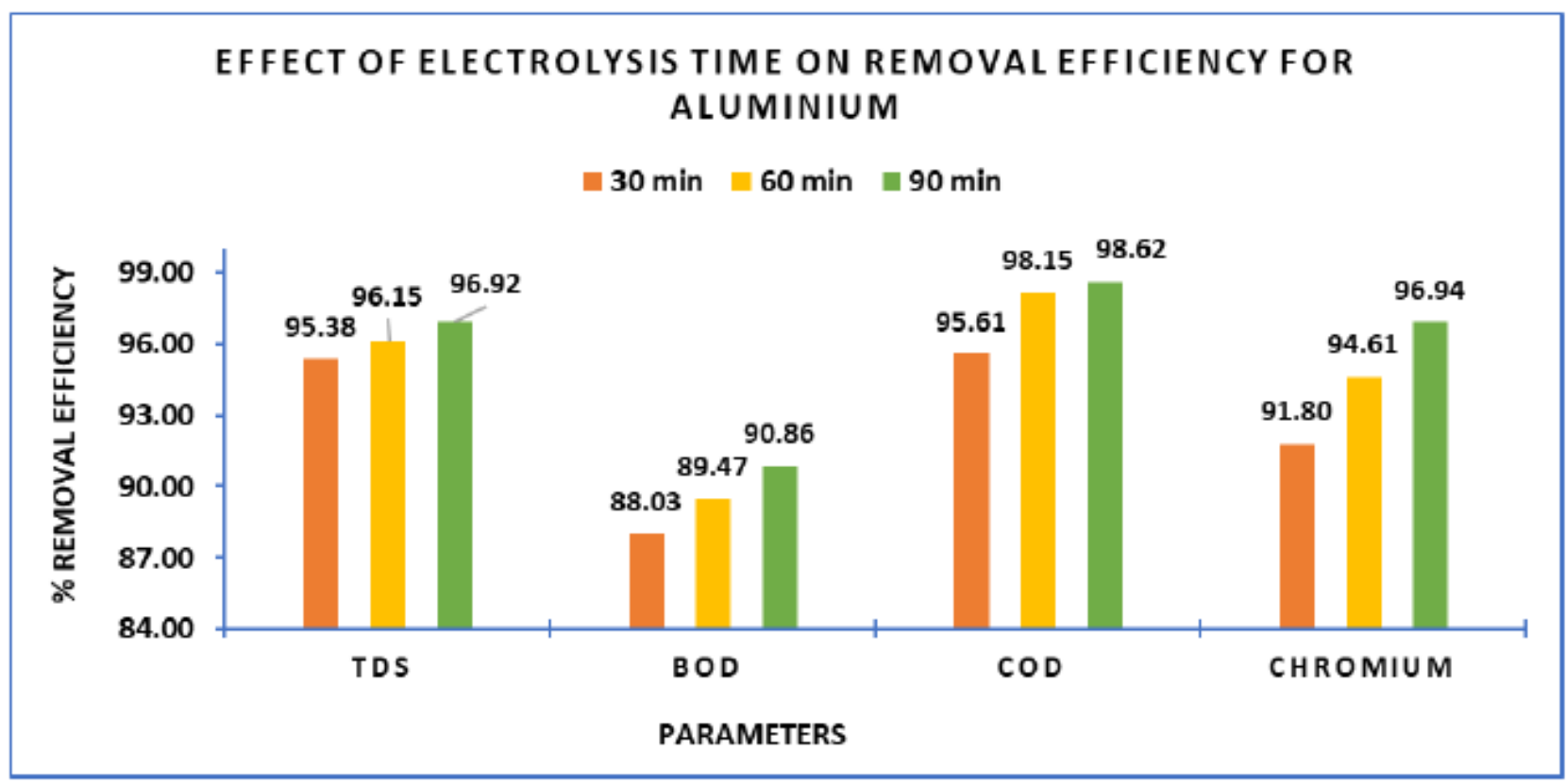

Figure 3.5 Effect of Electrolysis Time on Removal Efficiency for Aluminium Electrodes

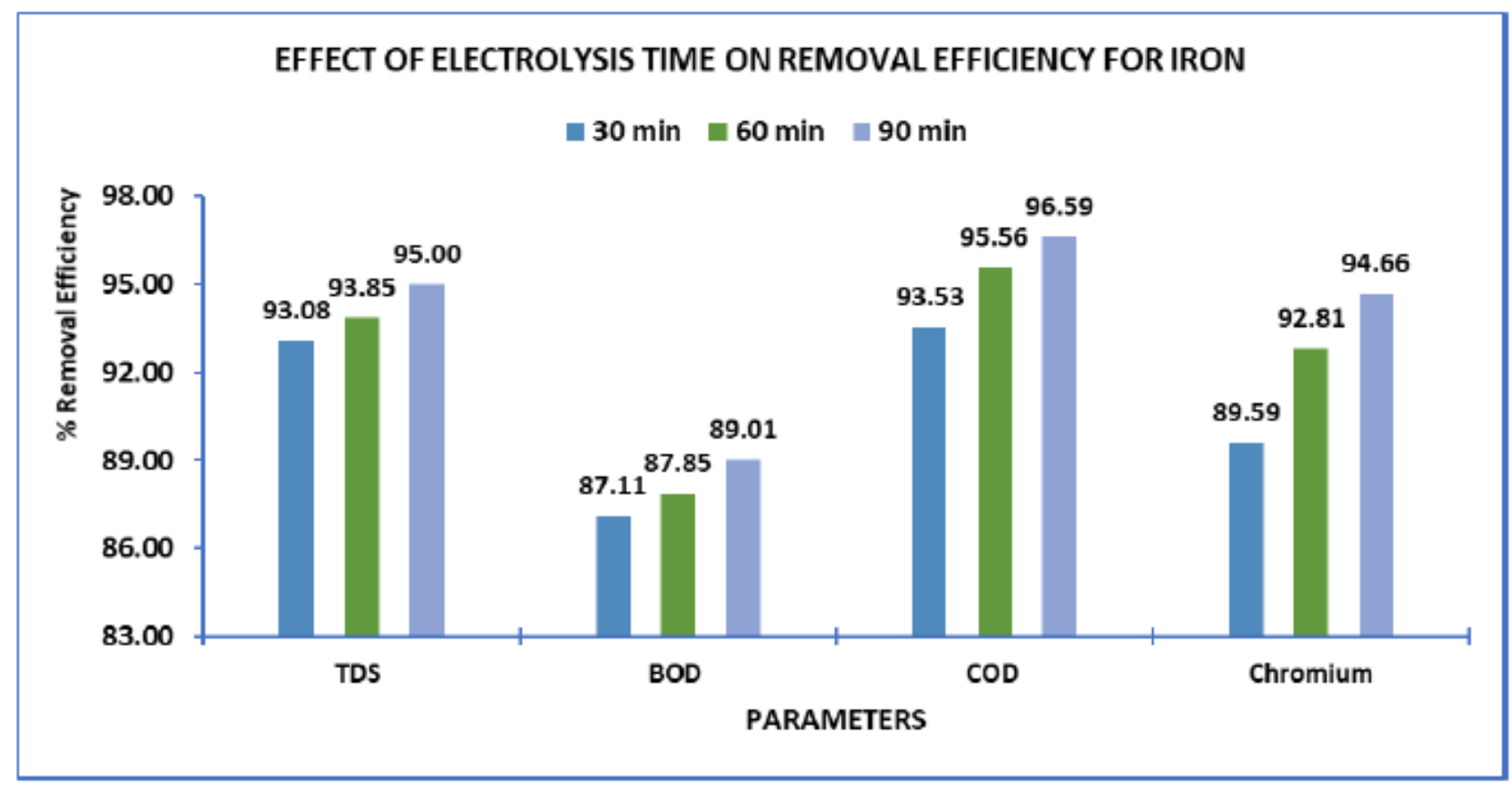

Figure 3.6 Effect of Electrolysis Time on Removal Efficiency for Iron Electrodes

\subsection{Effects of Electrode Distance on Removal Efficiency}

The Figure 3.7 and 3.8 were plotted to study the effect of electrode distance on removal efficiencies of TDS, BOD, COD and Chromium. It was observed that at $1 \mathrm{~cm}$ of electrode distance, $98.62 \%$ of COD removal efficiency was found. As the electrode distance increases the removal efficiency decreases. The graph shows removal efficiency of $96.92 \%$ and $94.54 \%$ at $1.5 \mathrm{~cm}$ and $2 \mathrm{~cm}$ electrode distance for punched aluminum electrodes and $96.59 \%, 94.13 \%$, and $90.48 \%$ for punched iron electrodes respectively, as the distance increases the faradaic yield and the potential difference between the electrodes decreases. Consequently, the amount of metal getting dissolved into the solution is reduced. Another possible reason for the higher recovery efficiency at lower inter-electrode distance is that, low interelectrode distances result in an electric field with high potential gradient and low resistance to motion of ions. This results in a faster formation of aluminum hydroxide $\mathrm{Al}(\mathrm{OH})_{3}$ and $\mathrm{Fe}(\mathrm{OH})_{3}$ species and in faster collision of electrode cations with that of the pollutants in the solution. 


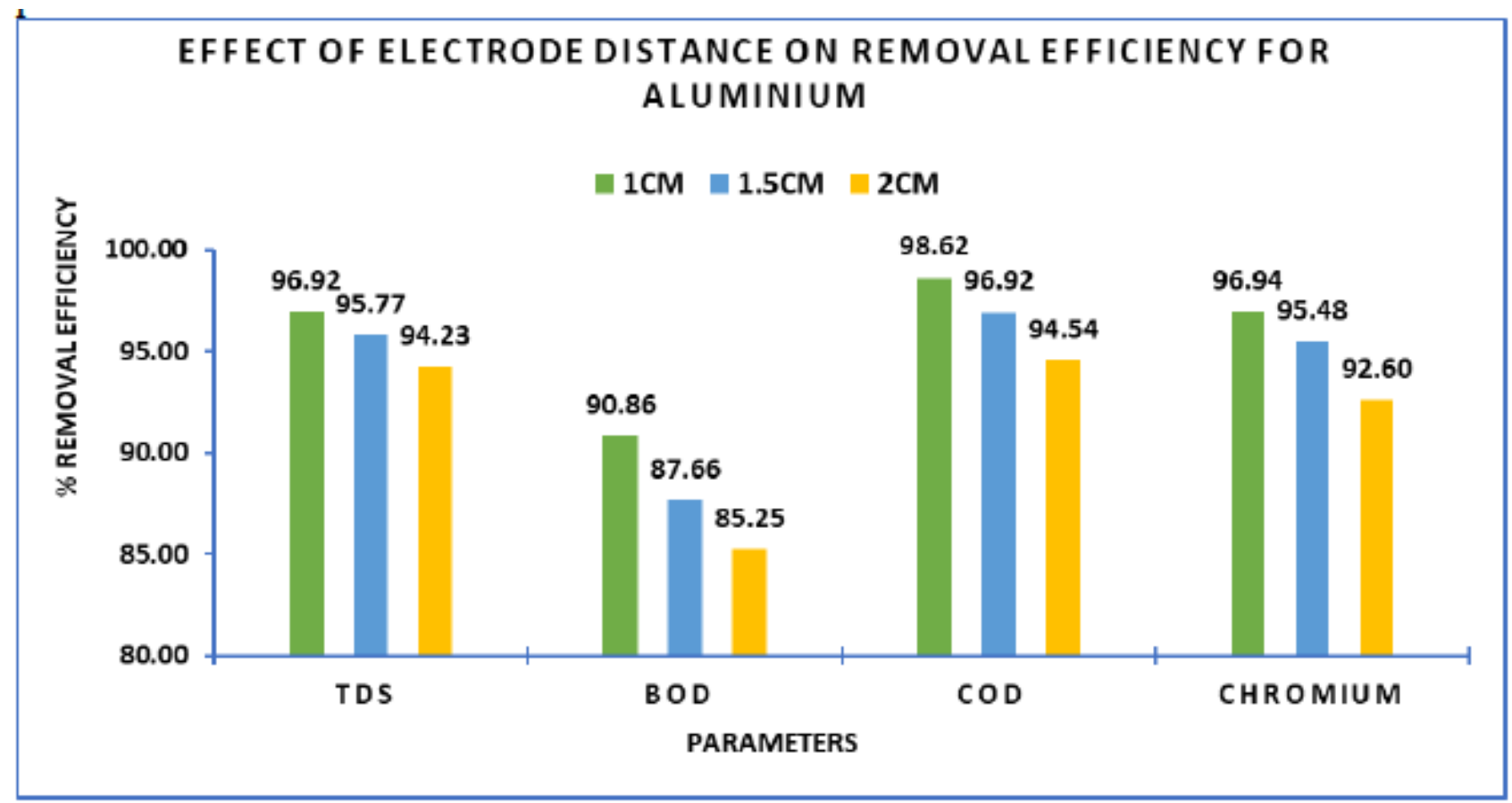

Figure 3.7 Effect of Electrode Distance on Removal Efficiency for Aluminium Electrodes

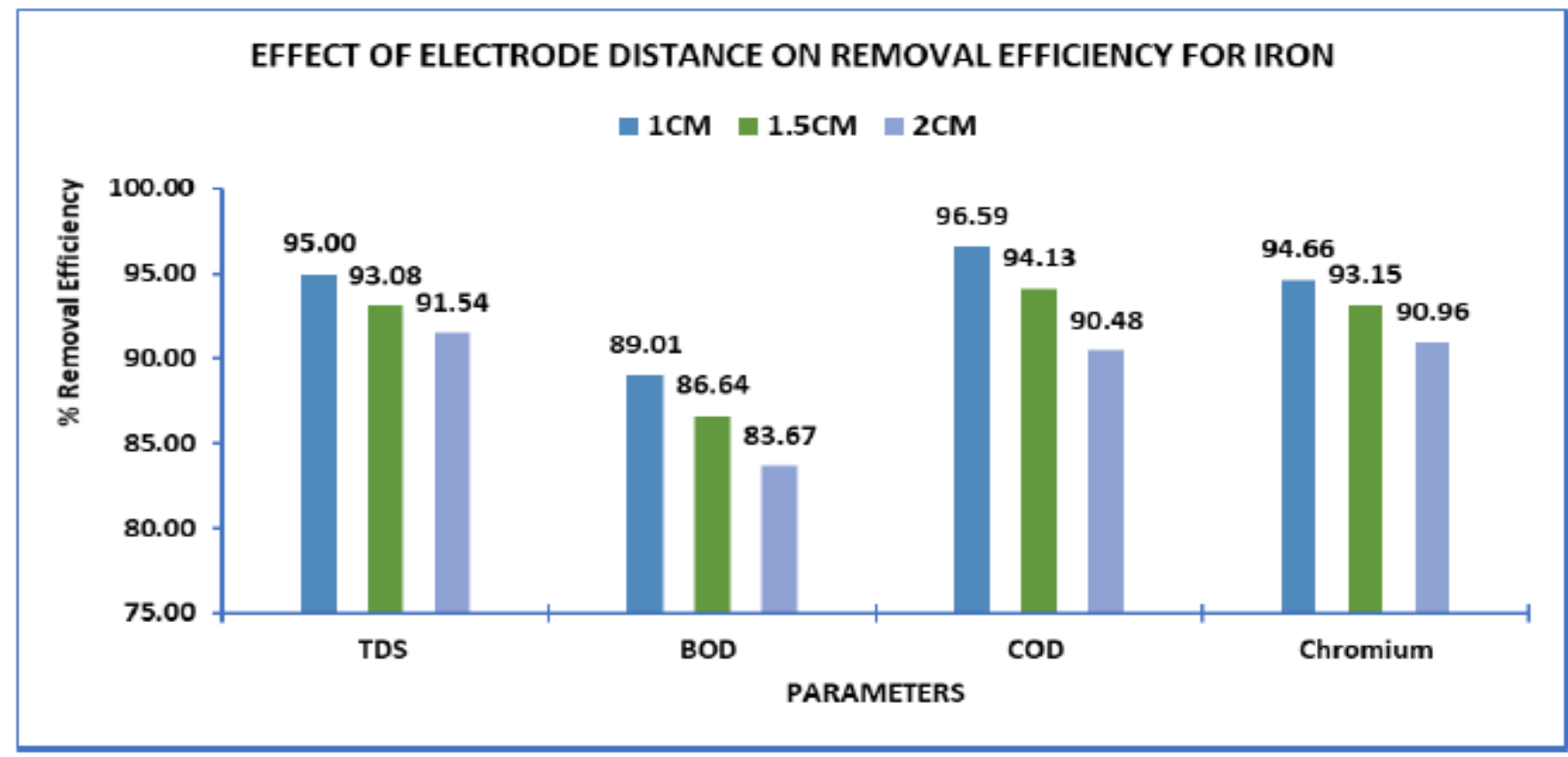

Figure 3.8 Ëfect of Ēlectrode Distance on Removäl Efficiency for Iron Electrodēs

3.5 Effects of Electrode Shape on Removal Efficiency

The Figure 3.9 and 3.10 were plotted to study the effect of electrode shape on removal efficiencies of TDS, BOD, COD and Chromium. It was observed that for plane aluminium and iron electrodes, $96.21 \% 94.77 \%$ of COD removal efficiency was found respectively. For punched aluminium and iron electrodes, 98.62\% 96.59\% of COD removal efficiency was found respectively. The shape of the electrodes affects the performance of the electrocoagulation. The punched electrodes provide greater surface area than the plane, as the electron density would be highest at the sharp edges, more electron accumulate at the holes and edges. These electrons carry more current and subsequently more reaction occur in the solution results in higher efficiency.
The electric field intensity at the edge of punched holes type electrodes is higher than at plane type electrode resulting in an increase in the discharge current at punched type electrode. Electric field intensity at the edge of punched holes type electrodes is higher (1.2 times) than at plane type electrode. More electron accumulate at the holes and edges, these electrons carry more current and subsequently more reactions occur in the solution results in higher efficiency thus, resulting in an increase in the discharge current at punched type electrodes. 


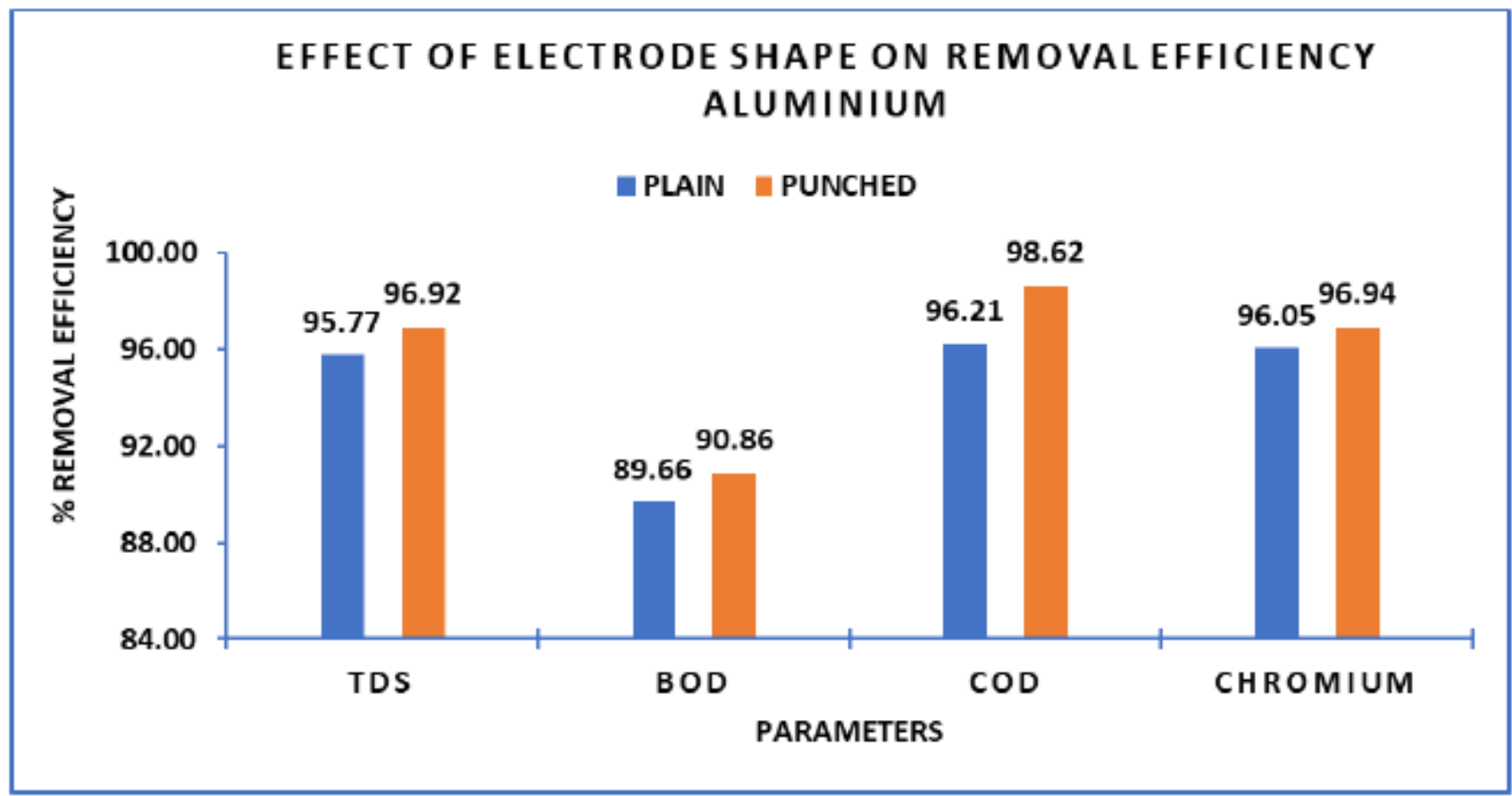

Figure 3.9 Effect of Electrode Shape on Removal Efficiency for Aluminium Electrodes

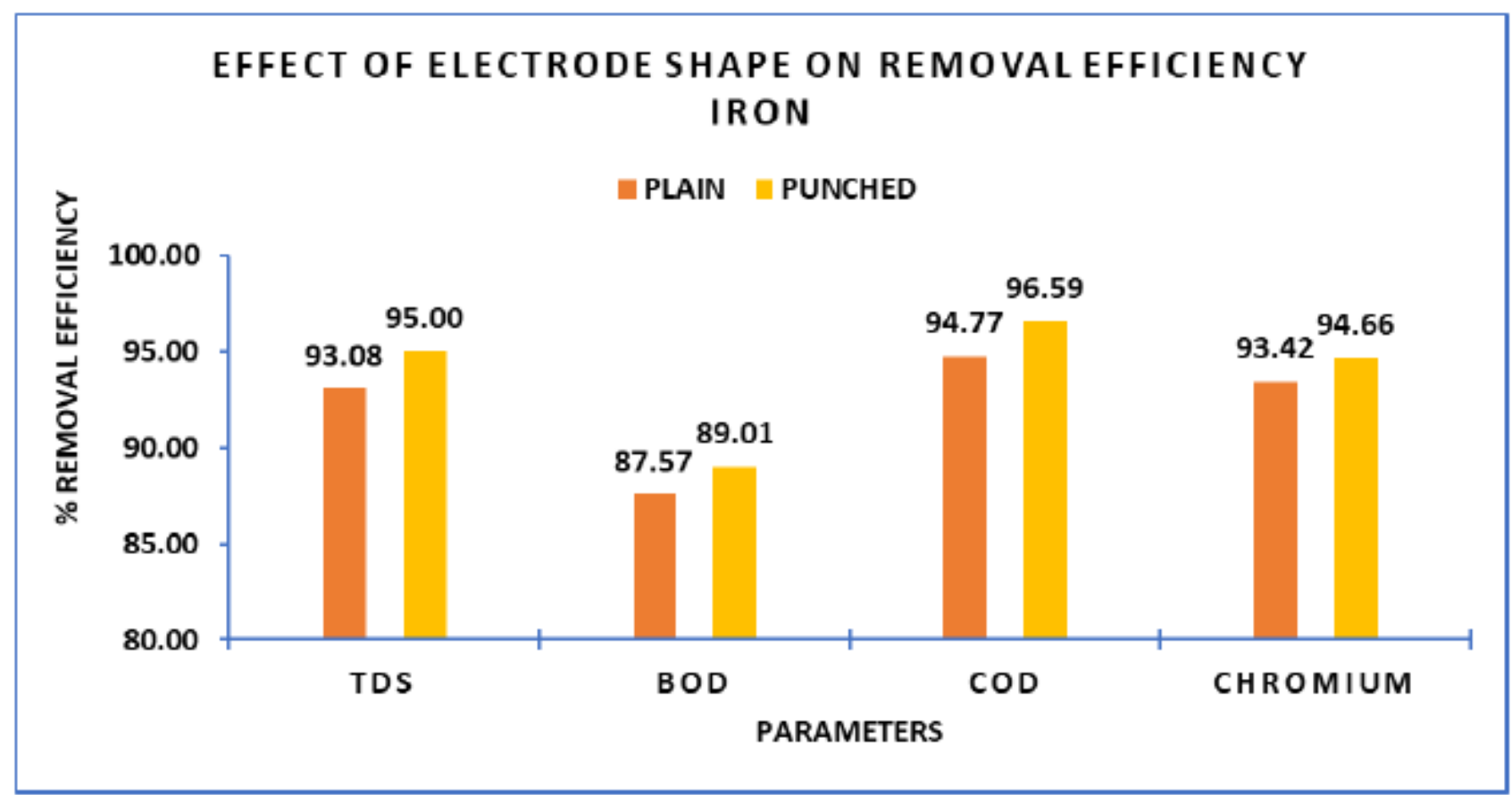

Figure 3.10 Effect of Electrode shape on Removal Efficiency for Iron Electrodes

\subsection{Effects of Electrode Material on Removal Efficiency}

The Figure 3.11 represents the graph plotted to study the effect of electrode material in removal efficiencies of various parameters such as TDS, BOD, COD and Chromium. The graphs reveal that all the parameters show highest removal efficiency for aluminum electrodes compared to iron.

The electrode material has a significant effect on the removal efficiency of the pollutants. The better performance of aluminum electrodes in comparison to iron is because iron hydroxides are relatively inefficient coagulants compared to aluminum hydroxides coupled to a higher faradaic yield with aluminum electrodes. 


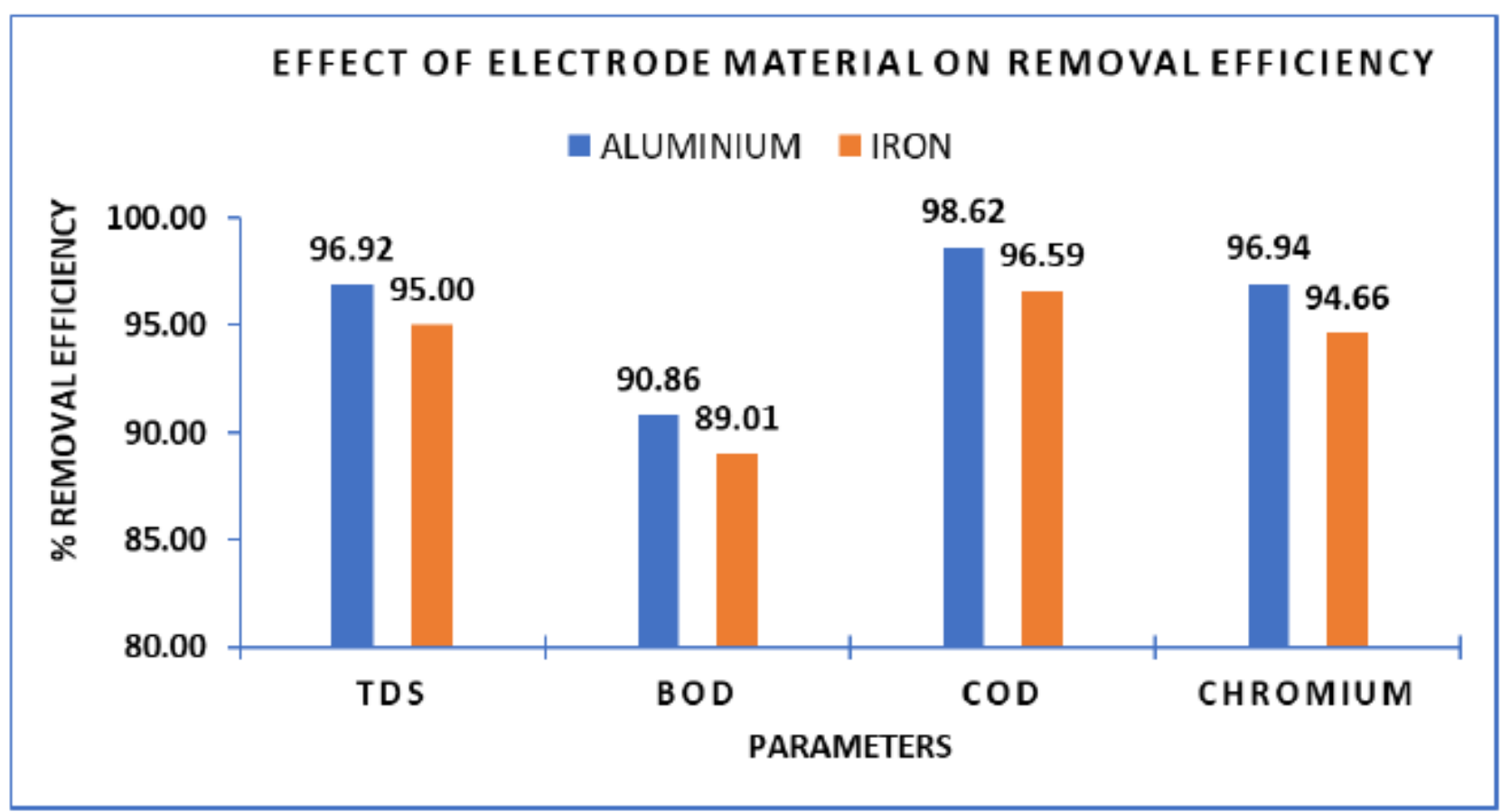

Figure 3.11 Effect of Electrode Material on Removal Efficiency

\section{CONCLUSIONS}

Based on the above finding the following conclusion are drawn

- The optimum condition for the removal of TDS, BOD, COD and Chromium from the tannery wastewater using aluminium and iron electrode was found to be at $\mathrm{pH}$ of 8 , voltage $20 \mathrm{~V}$, electrolysis time $90 \mathrm{~min}$, electrode distance of $1 \mathrm{~cm}$ for punched electrodes.

- It was observed that, the removal efficiency of all the parameters increased with increase in the $\mathrm{pH}$ of the solution, time, voltage. Whereas the efficiency increases with decrease in electrode distance for both aluminium and iron electrodes.

- Increase in $\mathrm{pH}$ was observed during the electrolysis process as the aluminium and iron electrodes get more dissolution. The alkaline $\mathrm{pH}$ of 8 is best suited for the maximum removal efficiency

\section{REFERENCES}

1. Saritha Banuraman and Meikandaan.T.P, "Treatability study of tannery effluent by enhanced primary treatment", International Journal of Modern Engineering Research (IJMER), Vol.3, 2013, Issue.1, pp119-122, ISSN 2249-6645.

2. Ramanujam R.A. Ganesh R. and Kandasamy J. "Wastewater treatment technology for tanning industry", Water and wastewater treatment technologies. Vol 4, 2011, pp. 1-17

3. Alebel Abebe Belay," Impacts of chromium from tannery effluent and evaluation of alternative treatment options", Journal of Environmental Protection, vol 1. 2010, pp53-58

4. Shivayogimath C.B, Prashant Kurdekar, "Treatment of Tannery wastewater by Electrocoagulation", International Journal of Innovative Research in Science, Engineering and Technology, Vol.3, 2013, Pp379-386.

5. Patel V.G, Uday Mawani, Manoj Bhavsar. "Leather and environment" Environmental information system Vol. 12, 2017, Issue no. 1, pp.1-12.
6. Ramesh Babu, Bhadrinarayana N.S, K.M.Meera Sheriffa Begum, N.Anantharaman," "Treatment of Tannery Wastewater by Electrocoagulation", Journal of the University of Chemical Technology and Metallurgy, Issue 42, Vol.2, 2007, pp.201-206.

7. Tinni S.H, Islam M. A, Fatima K, and Ali M. A. (2014), Impact of Tanneries Waste Disposal on Environment in Some Selected Areas of Dhaka City Corporation; J. Environ. Sci. \& Natural Resources, 7(1): 149-156, 2014 ISSN 1999-7361.

8. Keerthi, Vinduja V, Balasubramanian N (2013), Electrocoagulationintegrated hybrid membrane processes for the treatment of tannery wastewater. (2013); 20:7441-7449.

9. Deepika. J, Gengadevi R. R, \& Saravanan K. (2014), Efflluent treatment of tannery industries: Optimization of experimental data using RSM, Journal of Chemical Engineering and Research, Vol.2, No.1 (2014), pp 1-9.

10. Ebtesam El-Bestawy, Fahad Al-Fasi., Ranya Amer, Reham Aburokba (2013). Biological treatment of leather tanning industrial wastewater using free living bacteria. LNLS 2007 Activity Report.

11. Naik, S.J.K., Pawer, A.C., Vani, K., Madhuri, K and Devi, V.V, (2007), Cytogenic analysis in human to assess the Impact of metal pollution from Jeedimetla Industrial area, Hyderabad. A.P, Indian pollution Research, 26(2), pp. 263-265. 